\title{
Feasibility of integral water repellent admixtures in low pressure compatible injected fill grouts
}

\author{
C. Citto, A. E. Geister \& D. W. Harvey \\ Atkinson-Noland \& Associates, Inc., USA
}

\begin{abstract}
For almost two decades, compatible injected fill (CIF) grouts have been used in the restoration and repair of historic masonry structures. CIF materials are installed using a low-pressure injection process and often serve the dual purposes of structural strengthening and enhancement of moisture resistance. In the past, improved weather resistance was primarily the result of the CIF material filling voids in collar, head, and bed joints through which moisture could penetrate. However, the CIF materials were not specifically formulated for moisture resistance. The weather resistance of CIF installations could be significantly improved by increasing the water repellency of the CIF material. However, if this innovation comes at the expense of significant changes to other material properties, it may not be a viable approach.

This paper presents the ability of injected CIF material to improve the moisture resistance of masonry walls through a series of water penetration test results, and also describes a comparative study of CIF material properties in formulations with and without integral water repellent (IWR) admixture. Material properties relevant to typical CIF installations were evaluated using standard laboratory test procedures. Samples were tested for plastic properties, compressive strength, flexural bond strength, shear bond strength, vapor permeability, and water repellency. Tested samples used the same proprietary blend of cementitious materials, aggregate, and admixtures. The effects of IWR on material properties are discussed as well as overall feasibility of IWR admixtures in CIF materials.
\end{abstract}

Keywords: building envelope, CIF, grout injection, integral water repellent, masonry walls, moisture resistance, water penetration, water testing. 


\section{Introduction}

Compatible injected fill (CIF) materials are a valuable tool used in the restoration and repair of historic masonry structures. During the development of the CIF approach, an extensive experimental program was conducted by Atkinson and Schuller [1] to evaluate injection grouting procedures, different mix designs, and the effect on structural behavior of CIF injections. Nevertheless, experimental work by Albert [2] showed that water penetration through masonry cavity walls could be significantly reduced when filling the cavity by injection grouting. However, CIF materials were not specifically formulated for moisture resistance. The weather resistance of CIF installations could be further improved by increasing the water repellency of the CIF material. This paper illustrates results of an experimental investigation carried out to evaluate the influence of integral water repellant (IWR) admixture to relevant material properties of CIF. The testing performed on the CIF specimens was intended only as a qualitative comparison between mixes with and without IWR.

\section{Water penetration testing of masonry walls}

Two standardized test methods are commonly used to evaluate and compare masonry water penetration performance: the laboratory test in accordance with ASTM E514, Standard Test Method for Water Penetration and Leakage Through Masonry [3], and the corresponding field test in accordance with ASTM C1601, Test Method for Field Determination of Water Penetration of Masonry Wall Surfaces [4]. Both methods use a chamber mounted on a masonry surface to simulate a severe rainstorm producing approximately $5 \frac{1}{2}$ inches (140 $\mathrm{mm})$ of rain per hour and $62.5 \mathrm{mph}(27.9 \mathrm{~m} / \mathrm{s})$ wind for 4 hours. These methods are commonly used to evaluate and compare masonry water penetration performance.

ASTM E514 results by Albert [2] showed that injecting the cavity of brick veneer laboratory test panels with a conventional, non-IWR CIF reduced water penetration in a 2 -wythe brick wall from $12.4 \mathrm{~L} / \mathrm{hr}$ to $0.08 \mathrm{~L} / \mathrm{hr}$, a brick veneer on concrete block wall from $5.83 \mathrm{~L} / \mathrm{hr}$ to $0.64 \mathrm{~L} / \mathrm{hr}$, and brick veneer on steel stud drywall from $3.63 \mathrm{~L} / \mathrm{hr}$ to zero.

ASTM C1601 testing was performed by the authors on a single-wythe, split face concrete masonry building before and after the hollow cells in a section of wall were filled by injection grouting with a conventional, non-IWR CIF. Injection grouting reduced the water penetration rate by $68 \%$, from $60 \mathrm{~L} / \mathrm{hr}$ to 19 $\mathrm{L} / \mathrm{hr}$. Testing in numerous multi-wythe brick masonry walls has generally shown dramatic reductions in moisture infiltration after installation of CIF without IWR.

\section{Comparative experimental program}

The main purpose of this study was to investigate whether the water repellency of CIF could be improved with the addition of IWR without negatively affecting 
other CIF properties in a significant way. The addition of IWR should not compromise the capacity of the CIF material to fill small voids and cracks without segregation and bond to the surrounding masonry, should be compatible with the masonry being injected, and have adequate strength. To this end, three sets of specimens were prepared and tested, the first being designated the "base" mix without IWR, the second being a mix containing a liquid oleic acid IWR, and the third containing a powder calcium stearate IWR. Dosage of IWR was based on manufacturer's recommendations for mortar, which relate IWR to total binder content by weight. All other components and aspects of CIF mix formulation were kept identical. Testing involved the evaluation of plastic properties, hardened mechanical properties, and water resistivity of the three mixes.

\subsection{Plastic properties}

The first step of the experimental program was to characterize the three different mixes through the evaluation of their plastic properties. Fluidity was measured in accordance with ASTM C939, Standard Test Method for Flow of Grout for Preplaced-Aggregate Concrete (Flow Cone Method) [5]. After 3 minutes of electric mixing, the flow rate of each mix was tested using a 0.5 inch $(12.7 \mathrm{~mm})$ diameter flow cone, and the ratio of water to dry mix was adjusted accordingly to obtain consistency between the mixes before observing other properties and casting specimens. CIF mix stability was evaluated for each mix in accordance with ASTM C940, Standard Test Method for Expansion and Bleeding of Freshly Mixed Grouts for Preplaced-Aggregate Concrete in the Laboratory [6]. This test requires the evaluation of volume changes and accumulation of bleed water in a graduated cylinder. To compare the stability of the mix formulations, a more severe variation of ACI 423.9M-10, Test Method for Bleed Stability of Cementitious Post-Tensioning Tendon Grout [7] was used to measure water separation after 10 minutes under $10 \mathrm{psi}(68.9 \mathrm{kPa})$ pressure in a Gelman pressure cell. Stability is an important property of the CIF as segregation of the constituents during the injection process can result in incomplete filling of voids or inconsistent bonding and strength properties.

\subsection{Mechanical properties}

Different tests were conducted to evaluate the influence of the IWR on CIF mechanical properties. Comparison of compressive strength was determined by casting and testing CIF specimens in accordance with ASTM C1019, Standard Test Method for Sampling and Testing Grout [8]. In this test method, molds are made from masonry units to subject the CIF specimens to absorption conditions similar to those experienced by CIF material in the wall. Three samples were obtained from each mix. Flexural bond strength was determined in accordance with ASTM C1072, Standard Test Method for Measurement of Masonry Flexural Bond Strength [9]. The stack bond test prisms were created by filling the bed joints between bricks with CIF. A set of porous historic brick and a set of dense modern solid brick were used for each mix type to subject the CIF to 
different absorption conditions in the flexural bond strength test. Comparison of shear bond strength was determined by using a modified variation of California Test 644, Core Test for Shear Bond [10]. A two-wythe brick wall panel was constructed, and the cavity between wythes was filled with CIF. 28 days after casting CIF, cores were removed from the panel and the brick-CIF interface was tested in shear. Three cores were tested for each mix formula.

\subsection{Water repellency}

Water repellency properties were evaluated using adaptations of National Concrete Masonry Association (NCMA) tests for characteristics of concrete masonry units (CMU) with IWR. Water absorption was measured in accordance with variations of NCMA Methods CMU-WR1, Standard Test Method for Water Droplet and Water Stream Tests of Concrete Masonry Units [11] and CMUWR3, Standard Test Method for Assessing Water Uptake Potential of Concrete Masonry Units [12] were used. Since these tests are intended to be performed on portions of CMU face shells, CIF specimens were cast with dimensions similar to a CMU face shell, as seen in Figure 1, for this purpose. Three samples were made using the base mix and three using each IWR mix, and all tests were performed after a minimum cure time of 28 days. In the water droplet test, multiple drops of water were placed on the hardened CIF surface and the ability of the material to resist the absorption of water was evaluated over time based on visual observation. In the water uptake test, the oven-dried specimen is placed in 0.1 inch $(3 \mathrm{~mm})$ of water and the water absorption is evaluated by measuring the change in weight of the specimen for the next 24 hours.

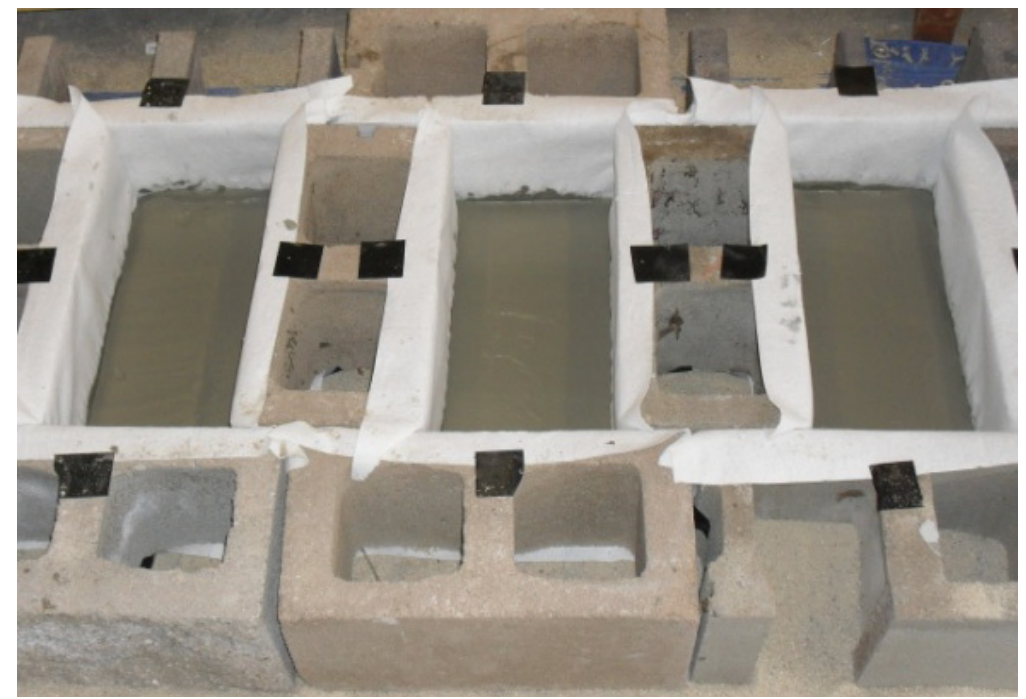

Figure 1: CIF specimens cast for water repellency testing. 


\subsection{Water vapor permeability}

Water vapor transmission (WVT) testing was conducted for each mix in accordance with ASTM E96, Standard Test Methods for Water Vapor Transmission of Materials [13]. Specimens for the WVT testing were prepared by sectioning CIF samples cast in absorptive brick molds with a water-cooled masonry saw. A minimum of four samples were obtained from each mix with dimensions of approximately 2.4 inches $(60 \mathrm{~mm})$ long by 2.4 inches $(60 \mathrm{~mm})$ wide by 0.6 inches $(15 \mathrm{~mm})$ thick. Samples were inserted into square plastic containers and sealed with silicone at all perimeter edges. Water was introduced into the wet cup by hypodermic needle and the puncture then sealed with silicone. All samples were placed in an environmental chamber with conditions maintained at $90^{\circ} \mathrm{F}\left(32^{\circ} \mathrm{C}\right)$ and relative humidity of $50 \%$. The temperature was controlled by a thermostat and heating element and the relative humidity was maintained by an open container of saturated Magnesium Nitrate Hexahydrate placed in the environmental chamber. This salt provides an equilibrium relative humidity of $50 \%$ at $90^{\circ} \mathrm{F}\left(32^{\circ} \mathrm{C}\right)$.

\section{Experimental results}

\subsection{Plastic properties}

Properties measured after mixing included flow rate, fluid density, expansion in a graduated cylinder and water separation under an applied pressure of $10 \mathrm{psi}$ $(68.9 \mathrm{kPa})$ for 10 minutes. The results of these plastic properties are presented in Table 1 . Note that slightly more water was required in both IWR mixes to achieve a similar flow rate as the Base mix. A very small amount of water separation was observed within 10 minutes under the applied pressure in all three mixes. CIF density decreased slightly with the addition of IWR, and the amount of initial expansion observed in the base mix was reduced to half in the calcium stearate IWR mix, and was reduced to zero in the oleic acid IWR mix.

Table 1: $\quad$ CIF mix plastic properties.

\begin{tabular}{|c|c|c|c|c|c|}
\hline $\begin{array}{c}\text { Mix } \\
\text { designation }\end{array}$ & $\begin{array}{c}\text { Flow } \\
\text { cone } \\
\text { time } \\
(\mathrm{sec})\end{array}$ & $\begin{array}{c}\text { Baroid } \\
\text { density } \\
\left(\mathrm{g} / \mathrm{cm}^{3}\right)\end{array}$ & $\begin{array}{c}\text { Final } \\
\text { expansion } \\
(\%)\end{array}$ & $\begin{array}{c}\text { Final } \\
\text { bleeding } \\
(\%)\end{array}$ & $\begin{array}{c}\text { Water } \\
\text { separation } \\
\text { under } \\
\text { pressure (ml) }\end{array}$ \\
\hline Base mix & 24 & 2.02 & $1.3 \%$ & 0 & 1 \\
\hline $\begin{array}{c}\text { Oleic acid } \\
\text { IWR mix }\end{array}$ & 27 & 2.00 & 0 & 0 & 1 \\
\hline $\begin{array}{c}\text { Calcium } \\
\text { stearate IWR } \\
\text { mix }\end{array}$ & 25 & 1.98 & $0.6 \%$ & 0 & 1 \\
\hline
\end{tabular}




\subsection{Mechanical properties}

CIF compressive strength was tested at an age of 28 days. Results are summarized in Table 2. Compressive strength results of the IWR mix formulas were about $15 \%$ to $30 \%$ lower on average, possibly due to the additional water required to achieve the same flow rate as the base mix. The aim of CIF, however, is generally not to achieve high values of compressive strength, but rather to be compatible with the surrounding materials, which may have very low compressive strengths.

Table 2: $\quad$ CIF 28 day compressive strength test results.

\begin{tabular}{|c|c|c|c|}
\hline & Base mix & $\begin{array}{c}\text { Oleic acid } \\
\text { IWR mix }\end{array}$ & $\begin{array}{c}\text { Calcium stearate } \\
\text { IWR mix }\end{array}$ \\
\hline $\begin{array}{c}\text { Compressive } \\
\text { strength, psi } \\
\text { (MPa) }\end{array}$ & $\begin{array}{c}9000 \\
(62)\end{array}$ & $\begin{array}{c}6900 \\
(48)\end{array}$ & $\begin{array}{c}7800 \\
(54)\end{array}$ \\
\hline $\begin{array}{c}\text { Standard } \\
\text { deviation, psi } \\
\text { (MPa) }\end{array}$ & $\begin{array}{c}110 \\
(0.8)\end{array}$ & $\begin{array}{c}210 \\
(1.4)\end{array}$ & $\begin{array}{c}280 \\
(1.9)\end{array}$ \\
\hline
\end{tabular}

Flexural bond strength was tested at an age of 28 days using the bond wrench apparatus described in ASTM C1072 [9]. Results, summarized in Table 3, saw an overall decrease in flexural bond strength of dense modern brick with the use of IWR, while still achieving very high values. More variation was observed the historic brick results, because failure generally occurred within the brick, indicating the CIF bond was stronger than the flexural tensile strength of the brick material.

Table 3: $\quad$ Flexural bond strength results.

\begin{tabular}{|c|c|c|c|}
\hline & Base mix & $\begin{array}{l}\text { Oleic acid } \\
\text { IWR mix }\end{array}$ & $\begin{array}{c}\text { Calcium } \\
\text { stearate IWR } \\
\text { mix }\end{array}$ \\
\hline $\begin{array}{c}\text { Flexural bond } \\
\text { strength with } \\
\text { modern brick, psi } \\
\text { (MPa) }\end{array}$ & $\begin{array}{l}340 \\
(2.4)\end{array}$ & $\begin{array}{l}250 \\
(1.7)\end{array}$ & $\begin{array}{l}190 \\
(1.3)\end{array}$ \\
\hline $\begin{array}{c}\text { Standard deviation, } \\
\text { psi (MPa) }\end{array}$ & $\begin{array}{c}210 \\
(1.5) \\
\end{array}$ & $\begin{array}{c}80 \\
(0.5)\end{array}$ & $\begin{array}{c}10 \\
(0.1) \\
\end{array}$ \\
\hline $\begin{array}{c}\text { Flexural bond } \\
\text { strength with } \\
\text { historic brick, psi } \\
(\mathrm{MPa})\end{array}$ & $\begin{array}{c}54 \\
(0.37)\end{array}$ & $\begin{array}{c}22 \\
(0.15)\end{array}$ & $\begin{array}{c}83 \\
(0.57)\end{array}$ \\
\hline $\begin{array}{c}\text { Standard deviation, } \\
\text { psi (MPa) }\end{array}$ & $\begin{array}{c}44 \\
(0.31)\end{array}$ & $\begin{array}{c}21 \\
(0.14)\end{array}$ & $\begin{array}{c}50 \\
(0.34)\end{array}$ \\
\hline
\end{tabular}


Shear bond strength was tested at an age of 28 days using a modification of California Test 644 [10]. Results are summarized in Table 4. Test results were higher with the addition of IWR, indicating that its use does not likely have a negative effect on shear bond strength.

Table 4: $\quad$ Shear bond strength test results.

\begin{tabular}{|c|c|c|c|}
\hline & Base mix & $\begin{array}{c}\text { Oleic acid } \\
\text { IWR mix }\end{array}$ & $\begin{array}{c}\text { Calcium } \\
\text { stearate IWR } \\
\text { mix }\end{array}$ \\
\hline $\begin{array}{c}\text { Shear strength, psi } \\
(\mathrm{MPa})\end{array}$ & 110 & 115 & 150 \\
$(0.75)$ & $(0.8)$ & $(1.0)$ \\
\hline $\begin{array}{c}\text { Standard deviation, } \\
\text { psi }(\mathrm{MPa})\end{array}$ & 36 & 16 & 35 \\
& $(0.25)$ & $(0.11)$ & $(0.24)$ \\
\hline
\end{tabular}

\subsection{Water repellency}

The addition of IWR appears to improve the water repellency performance of the CIF in the water droplet test. Although this test is subjective in nature, the results showed significantly better performance by the IWR mix than the base mix. Using the nomenclature of the observation scale given in the test method, after 30 minutes, over $70 \%$ of the base mix droplets were considered "Totally absorbed," and after 60 minutes, over 85\% were considered "Dry." All of the oleic acid IWR mix droplets were either "Standing" or "Partially absorbed" after 60 minutes. $60 \%$ of the calcium stearate mix droplets were considered "Partially absorbed" after 60 minutes, one third were considered "Totally absorbed" and the remaining droplets were considered "Dry."

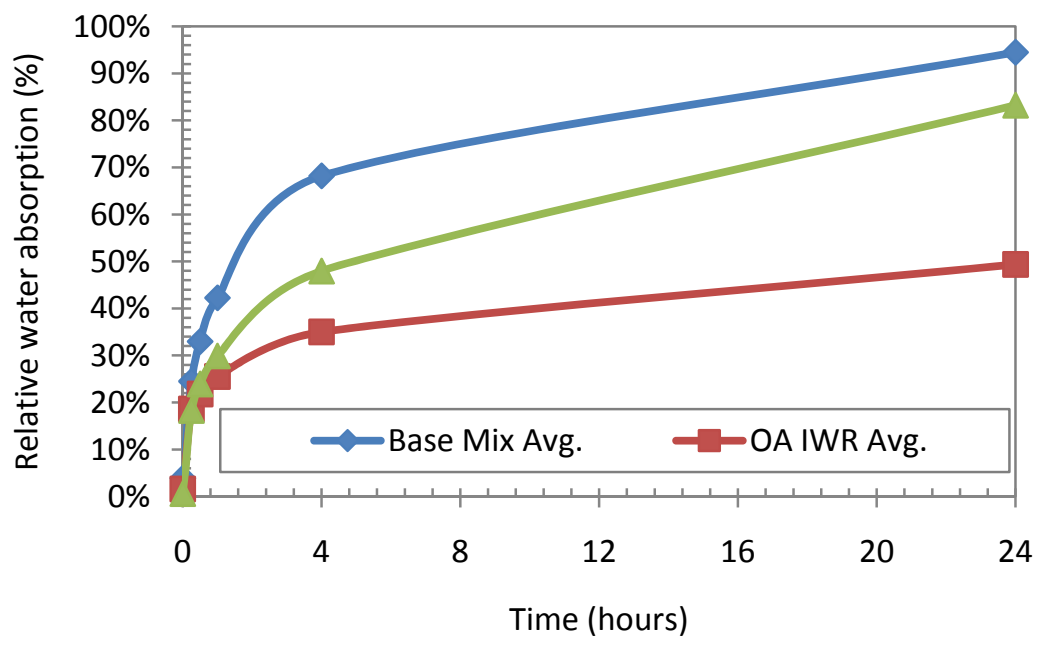

Figure 2: $\quad$ Relative water uptake results. 
Water uptake testing was performed on CIF samples in accordance with NCMA WR3 [12]. Average results in Figure 2 show an improvement in water uptake resistance with the use of IWR. Water uptake performance was improved with the addition of IWR. While 4 out of 5 base mix specimens reached $90 \%$ of total water absorption before the 24 hour measurement, only 2 out of 5 of the calcium stearate IWR specimens reached $90 \%$ by the 24 hour measurement, and none of the IWR mix specimens reached $50 \%$ by the 24 hour measurement.

\subsection{Water vapor permeability}

Results of water vapor transmission test are shown in Table 5. Similar behavior in terms of change in weight over time was observed for all three mixes. However, the oleic acid IWR mix experienced a reduction in WVT rate, while the calcium stearate IWR mix experienced an increase in WVT rate. These relatively small changes in water vapor permeability are unlikely to result in substantially different wall performance in most applications.

Table 5: $\quad$ Water vapor permeability test results.

\begin{tabular}{|c|c|c|c|}
\hline & Base mix & $\begin{array}{c}\text { Oleic acid } \\
\text { IWR mix }\end{array}$ & $\begin{array}{c}\text { Calcium } \\
\text { stearate IWR } \\
\text { mix }\end{array}$ \\
\hline $\begin{array}{c}\text { Permeability, } \\
\text { Perm·inch } \\
(\mathrm{g} / \mathrm{Pa} \cdot \mathrm{s} \cdot \mathrm{m})\end{array}$ & $\begin{array}{c}4.2 \\
\left(6.1 \times 10^{-9}\right)\end{array}$ & $\begin{array}{c}3.3 \\
\left(4.8 \times 10^{-9}\right)\end{array}$ & $\begin{array}{c}6.1 \\
\left(8.8 \times 10^{-9}\right)\end{array}$ \\
\hline $\begin{array}{c}\text { Standard deviation, } \\
\text { Perm·inch } \\
(\mathrm{g} / \mathrm{Pa} \cdot \mathrm{s} \cdot \mathrm{m})\end{array}$ & $\begin{array}{c}0.8 \\
\left(1.1 \times 10^{-9}\right)\end{array}$ & $\begin{array}{c}0.6 \\
\left(0.8 \times 10^{-9}\right)\end{array}$ & $\begin{array}{c}0.6 \\
\left(0.8 \times 10^{-9}\right)\end{array}$ \\
\hline
\end{tabular}

\section{Conclusions}

A review of the use of compatible injected fill (CIF) grout for the use of increasing the water resistance of masonry walls was presented. A series of tests performed before and after filling the wall cavity with CIF showed that water penetration could be significantly reduced even though CIF had not been specifically formulated for water resistance.

The influence of integral water repellent on material properties of CIF was evaluated. Tests were carried out on CIF specimens cast with and without integral water repellent. Samples were tested for plastic properties, compressive strength, flexural bond strength, shear bond strength, vapor permeability, and water repellency. The comparative study showed that plastic properties are slightly affected by IWR as a small amount of additional water was needed to achieve the required flow rate. Furthermore, the water repellency performance of the CIF was improved with the addition of IWR. Lower values of compressive strength were observed in each IWR mix, with an average reduction in the range of $15 \%$ to $30 \%$, however, compatibility with surrounding materials is generally 
more important in CIF installations than high values of compressive strength. Flexural bond strength results were variable, but still achieved very high bond strength values on dense modern brick, and lower strength results on softer historic brick resulting from failure of the brick material itself, rather than the CIF bond. Shear bond strength appeared to be unaffected by the use of IWR. The water vapor transmission rate of the oleic acid IWR mix decreased, while the mix containing calcium stearate IWR experienced an increase in water vapor transmission rate. In general, it appears that the use of IWR in CIF installations would likely be an effective approach to increasing water repellency of masonry walls.

\section{References}

[1] Atkinson, R.H., Schuller, M.P., Evaluation of Injectable Cementitious Grouts for Repair and Retrofit of Masonry, Masonry: Design and Construction, Problems and Repair, ASTM STP 1180, eds. J. M. Melander and L. R. Lauersdorf, American Society for Testing and Materials, Philadelphia, 1993.

[2] Albert, S.D., The Effectiveness of Grout Injection in Preventing Water Penetration Through Masonry Cavity Walls, Supported by National Science Foundation Grant No. MSS-9114511, 1996.

[3] ASTM E514. Standard Test Method for Water Penetration and Leakage Through Masonry, Annual Book of ASTM Standards,Vol. 04.05. ASTM, West Conshohocken, PA, 2009.

[4] ASTM C1601. Test Method for Field Determination of Water Penetration of Masonry Wall Surfaces, Annual Book of ASTM Standards,Vol. 04.05. ASTM, West Conshohocken, PA, 2010.

[5] ASTM C939. Standard Test Method for Flow of Grout for PreplacedAggregate Concrete (Flow Cone Method), Annual Book of ASTM Standards, Vol. 04.02. ASTM, West Conshohocken, PA, 2010.

[6] ASTM C940. Standard Test Method for Expansion and Bleeding of Freshly Mixed Grouts for Preplaced-Aggregate Concrete in the Laboratory, Annual Book of ASTM Standards, Vol. 04.02. ASTM, West Conshohocken, PA, 2003.

[7] ACI 423.9M-10. Metric Test Method for Bleed Stability of Cementitious Post-Tensioning Tendon Grout, Joint ACI-ASCE Committee 423. American Concrete Institute, Farmington Hills, MI, 2010.

[8] ASTM C1019. Standard Test Method for Sampling and Testing Grout, Annual Book of ASTM Standards, Vol. 04.05. ASTM, West Conshohocken, PA, 2009.

[9] ASTM C1072. Standard Test Method for Measurement of Masonry Flexural Bond Strength, Annual Book of ASTM Standards, Vol. 04.05. ASTM, West Conshohocken, PA, 2010.

[10] California Test 644, Method of Test for Shear Strength of Brick Cores, California Department of Transportation, 2000. 
668 Structural Repairs and Maintenance of Heritage Architecture XII

[11] NCMA Method CMU-WR1-09. Standard Test Methods for Water Droplet and Water Stream Tests of Concrete Masonry Units, National Concrete Masonry Association, 2009.

[12] NCMA Method CMU-WR3-09. Standard Test Method for Assessing Water Uptake Potential of Concrete Masonry Units, National Concrete Masonry Association, 2009.

[13] ASTM E96. Standard Test Methods for Water Vapor Transmission of Materials, Annual Book of ASTM Standards, Vol. 04.06. ASTM, West Conshohocken, PA, 2010. 